\title{
Bláha, Obrdlík a Eubank: brněnské kontakty s americkými sociology v souvislostech mezinárodní sociologie ${ }^{1}$
}

\author{
Bláha, Obrdlík and Eubank: The Contacts between Brno \\ and American Sociologists against the Backdrop of Interwar \\ International Sociology
}

Marek Skovajsa

\begin{abstract}
This paper examines the relations of the interwar sociologists in Brno with their American colleagues and international sociology in general. It describes the international contacts of Inocenc Arnošt Bláha and Antonín Obrdlík in the 1930s with a special focus on the professional and personal liaison between these two and American sociologist Earle Edward Eubank. These contacts are subsequently located within an imperfect, but genuine homology that existed between Czech sociology on the one hand and American and international sociology on the other. Previous research has shown that inside the international sociology of the 1930s, which centred around the Institut International de Sociologie (IIS), the eclectic French sociologists who controlled the IIS allied with American detractors of scientism, whereas their principal opponents, the Durkheimians, were close to the sociologists at the University of Chicago. In terms of their international networks and their substantive positions, Bláha's Brno group was part of the anti-scientist alliance, whereas the sociologists in Prague displayed an affinity for the Chicago School in particular. To substantiate this claim, the paper shows that the American networks of Obrdlík and Otakar Machotka (Prague), both Rockefeller fellows and later exiles in the US, were highly consistent with the observed divisions in American and international sociology.
\end{abstract}

KEYWORDS Inocenc Arnošt Bláha, Antonín Obrdlík, Earle Edward Eubank, Pitirim A. Sorokin, Czech sociology, US sociology, international sociology, Institut International de Sociologie

Jednoho srpnového večera roku 1934 došlo na Hlavním nádraži v Brně k setkání, které by $v$ dějinách české sociologie nemělo upadnout do zapomnění. Earle Edward Eubank (18871945) a Inocenc Arnošt Bláha (1879-1960) si do té chvíle už stačili vyměnit desítku dopisů

Sociální studia / Social Studies SPEC/2020. S. 35-52. ISSN 1214-813X.

1 Autorova práce na článku byla podpořena z prostředků Institucionální podpory na dlouhodobý koncepční rozvoj výzkumné organizace 2020 pro Univerzitu Karlovu. Analýza částečně vychází z materiálů získaných v amerických archivech díky projektu Grantové agentury České republiky 13-15802S „Od Rockefellera k Sorosovi“. 
a krátkých zpráv. Vše začalo v březnu téhož roku, kdy Eubank Bláhovi napsal, že se v létě chystá na velkou cestu po Evropě s cilem navštivit všechny významné evropské sociology, a požádal Bláhu o schůzku. ${ }^{2}$ Když se sešli, Bláha udělal vše pro to, aby americký host odjižděl s co nejlepšimi vzpominkami. Ubytoval jej doma ve své vile v Pisárkách, Bláhova služebná připravila bohatou večeři a oba muži strávili celý večer v prátelském rozhovoru. Druhý den Bláha svého hosta vzal autem na Macochu a večer se loučili jako staří známí.

Eubank a Bláha se nikdy znovu nesetkali, stali se však práteli a spojenci, psali si a navzájem se podporovali. Bláha Eubanka seznámil se svou dcerou Soňou (1914-2009) a jejím manželem Antonínem Obrdlikem (1905-1997), kteři byli oba rovněž sociology. Když Obrdlikovi $v$ letech 1935-1936 díky stipendiu Rockefellerovy nadace pobývali v USA, Eubank „Tošovi“ “ pomáhal navázat co nejvice kontakti̊ v americké sociologické obci. Dva dny po okupaci Československa hitlerovským Německem, 17. března 1939, Eubank Obrdlikovi z vlastní iniciativy poslal mistoprísežné prohlášení (affidavit of support) nutné pro získání amerického viza. Napsal desitky dopisů, aby svému mladšimu přiteli zajistil pedagogické misto na některé $z$ amerických univerzit, což byla dalši podmínka pro udělení víza. Nakonec celé jeho rodině $z$ vlastni kapsy zaplatil lodni listky do Ameriky a přispěl i na Obrdlikovu mzdu na Hiram College v Ohiu, kde pro něj domluvil aspoň jednoroční smlouvu. V polovině ledna 1940 Obrdlik psal Eubankovi už z New Yorku, že konečně jsou , ve svobodné zemi-výhradně díky Vám “" 4,5

Tolik ve stručnosti příběh přátelského vztahu Earle E. Eubanka s I. A. Bláhou a jeho zetěm Antonínem Obrdlíkem zrekonstruovaný na základě Eubankovy pozůstalosti. Německý socio$\log$ Dirk Käsler jej ve své eubankovské monografii Sociologická dobrodružství popsal poměrně podrobně, a není proto nutné opakovat každý detail (Käsler 1991, s. 95-100, 157-162). Eubankova pomoc Obrdlíkově rodině na začátku druhé světové války je vzácným př́íkladem obětavosti a humanismu prokazovaných konkrétními činy. V sociologické analýze by ale nemělo být přehlédnuto, že obsah vztahů mezi členy tria Eubank - Bláha - Obrdlík netvořilo jen osobní prátelství, ale také profesní spojenectví: vzájemně výhodná strategická směna informací, kontaktů, odborných poznatků, publikačních příležitostí, př́ležitostí ke kariérnímu rozvoji a ke zvýšení vlastní odborné prestiže. Jazykem Randalla Collinse lze říci, že v rámci struktury príležitostí představované meziválečnou mezinárodní sociologií tito tři sociologové vytvořili alianci, protože každý z nich ze vzájemných kontaktů získával užitečný kulturní kapitál a emocionální energii (Collins 1998, s. 37-40). Důvodem, proč Eubank v roce 1934 navštívil Bláhu a další evropské sociology, bylo shromažd’ování materiálů pro připravovanou monumentální knihu o světové sociologii, která měla vyjít ve dvou dílech nazvaných The Making of Sociology (dějiny sociologie v nejdůležitějších zemích) a The Makers of Sociology (profily několika desítek nejvýznamnějších světových sociologů). Eubank knihu

\footnotetext{
Dopis Earle E. Eubank - I. A. Bláha 30. 3. 1934, kt. 1, Eubank Papers, University of Chicago.

Podle Bláhy Obrdlíkovi půjčku Eubankovi postupně spláceli (Bláha 1996-2004: 162).

Dopis Antonín Obrdlík - Earle E. Eubank 14. 1. 1940, kt. 4, Eubank Papers, University of Chicago. Earle E. Eubank: „Dr. Arnost Blaha“ 23. 8. 1934, Eubankova korespondence s Bláhou a Obrdlíkem a související dokumenty, kt. 1, 4 a 8, Eubank Papers, University of Chicago. Viz také Bláhovy vzpomínky (Bláha 1996-2004, s. 90).
} 
nikdy nedokončil, z ambiciózního plánu zůstal jen rozsáhlý fond dokumentů a př́pravných studií. V Obrdlíkovi, který vedle angličtiny ovládal francouzštinu, němčinu a některé slovanské jazyky, viděl svého hlavního pomocníka př̀i př́ípravě publikace (opět Käsler 1991, s. 1-3). Naopak pro Obrdlíka měl jejich přátelský a zároveň spojenecký vztah nedocenitelnou hodnotu díky Eubankově velmi dobrému postavení v rámci americké sociologie, solidní akademické pověsti a rozsáhlým americkým i mezinárodním konexím.

Individuální přátelství a spojenectví Bláhy a Obrdlíka s Eubankem představuje jen drobný dílek složitějšího celku, kterým jsou mezinárodní vztahy české sociologie v meziválečném období. Kontakty tohoto druhu obvykle nejsou výsledkem pouhé náhody a nezakládají se jen na osobních sympatiích, jakkoli se tak účastníkủm mnohdy jeví. V tomto článku budu hájit tezi, podle níž prátelské spojenectví uvedené trojice mělo svůj strukturální předpoklad, jímž byla podobná logika uspořádání neboli strukturální homologie mezi americkou a českou sociologií. Př̌i utváření této homologie hrály důležitou zprostředkující roli mezinárodní sociologické sítě tehdejší doby, jež zase odrážely logiku uspořádání sociologie francouzské. Předmětem zájmu zde proto budou vztahy hlavních představitelů meziválečné české sociologie k protagonistům mezinárodní sociologie, kterou tvořil pařížský Mezinárodní sociologický institut (Institut International de Sociologie - IIS) a s ním spojení př́islušníci různých národních sociologií. Cílem analýzy je ukázat, že mezinárodní kontakty, afinity a averze českých meziválečných sociologů $\mathrm{v}$ zásadě odpovídají tezi o strukturální homologii mezi českou a mezinárodní sociologií. To znamená, že bylo-li základním dělením uvnitř meziválečné české sociologie dělení na brněnskou a pražskou skupinu, pak členové každé skupiny měli sklon 1. navazovat profesní i osobní kontakty se zahraničními sociology podobně umístěnými ve struktuře mezinárodní sociologie nebo př́slušné národní sociologie a 2 . zaujímat odborné nebo i politické pozice shodné nebo blízké pozicím zaujímaným jim strukturálně odpovídajícími skupinami v jiných sociologiích (srov. Bourdieu 2010, s. 303-308). V pozdějších částech článku se na př́kladu Antonína Obrdlíka (a jeho rivala z pražské skupiny Otakara Machotky, který představuje téměř ideální kontrastní případ) pokusím ukázat, že specifické umístění v poli české sociologie mohlo mít díky existujícím homologiím závažné důsledky pro akademickou dráhu českých sociologů $\mathrm{v}$ zahraničí, at' už šlo o průběh jejich stipendijních pobytů, nebo dokonce o základní otázku pokračování, či ukončení jejich kariéry po emigraci.

Abstraktní modely intelektuálních polí, s nimiž pracuje strukturálně zaměřené zkoumání dějin sociologie, mohou svádět $\mathrm{k}$ ahistorické interpretaci. Je proto třeba upřesnit, že následující výklad se týká období od poloviny 20 . let do konce 30 . let minulého století, a tomu také odpovídají použité archivní prameny a dokumenty. Klíčovým momentem tohoto období se ukázal být poslední předválečný kongres IIS v Paříži v roce 1937, který znamenal zlom ve vývoji IIS a také důležitý mezník ve vztazích české a mezinárodní sociologie. Na omezenou historickou platnost zkonstruovaného modelu mezinárodní sociologie poukáže poslední část a závěr článku.

\section{Dosavadní bádání}

V historii sociologie se $\mathrm{v}$ posledním desetiletí věnuje značná pozornost vlivu transatlantických cest a kontaktů na rozvoj národních sociologií (např. Fleck [2015] nebo kolektivní 
monografie Schrecker [2010] a v nich uvedená starší literatura). Zjištění vlivu určité návštěvy nebo kontaktu na práci určitého sociologa, nebo dokonce na směřování celé národní sociologie je však obtížné vzhledem $\mathrm{k}$ tomu, že vliv jednoho zdroje se obvykle doplňuje nebo kříží s různými dalšími vlivy a zdrojové podněty nejsou zejména v zajímavějších případech opravdu originálních sociologů přejímány mechanicky, nýbrž recipienti je intelektuálně zpracovávají a rekontextualizují. V neposlední řadě hraje roli i skutečnost, že historické prameny a dokumenty umožňující sledovat působení různých vlivů jsou neúplné a nelze se plně spoléhat ani na autobiografická nebo biografická svědectví ( $\mathrm{k}$ tomu některé př́spěvky v Moebius a Ploder 2017). Svou hodnotu pro dějiny sociologie však má i samotné shromažd'ování dokladů o pravděpodobných vlivech mezi určitými zdroji a prŕjemci, nebot' takové doklady se někdy mohou stát oporou pro interpretaci díla přijímajícího autora. Přesto jsou možnosti př́istupu založeného na stopování jednotlivých vykazatelných vlivů omezené. Opačnou alternativu $\mathrm{k}$ němu představuje holistická rekonstrukce obou (př́ípadně vícero) intelektuálních polí, mezi nimiž transfer probíhá, tedy pole zdrojové sociologie i pole sociologie přijímající (Bourdieu 2002). Taková rekonstrukce je však vždy konstrukcí, do níž mohou snadno proniknout ne zcela průkazné interpretace dostupného, opět nutně neúplného, materiálu. V tomto článku postupuji střední cestou mezi pozitivistickým vykazováním individuálních kontaktů a vlivů na jedné straně a abstrahujícím modelováním intelektuálních polí na straně druhé. Zjištění z archivních pramenů a publikací o vztazích českých sociologů se zahraničními kolegy a o jimi sdílených, nebo naopak odmítaných odborných a politických pozicích jsou interpretována s odkazem $\mathrm{k}$ prř́slušným konstruktům vypracovaným $\mathrm{v}$ literatuře: poli české meziválečné sociologie (Nešpor a Janák in Nešpor a kol. 2014: 146-214), americké sociologie (Bannister 1987; Turner a Turner 1990), francouzské sociologie (Clark 1973; Heilbron 2015) a v neposlední řadě mezinárodní sociologie (Turner 2010).

V dějinách české sociologie se tématu vztahů se zahraniční sociologií a zahraničních vlivů věnovala nedostatečná pozornost. Reprezentativní Dějiny české sociologie poskytují řadu jednotlivých informací, ale systematickému zpracování mezinárodních souvislostí se vyhýbají, protože chyběly př́islušné výzkumy (Nešpor a kol. 2014, s. 14). České práce o americké sociologii z nedávné doby probírají meziválečné období vcelku podrobně, ale vztahy k české sociologii se nezabývají (např. Balon 2011). Zatím největší úsilí o zohlednění zahraničního kontextu meziválečné české sociologie představují komparativní dějiny starší sociologie ve střední Evropě (Janák 2018), které se ale opravdu soustřed’ují na souvislosti s vývojem pouze $\mathrm{v}$ sousedních středoevropských zemích. Vztahy meziválečné české sociologie se vzdálenějšími národními sociologiemi a s mezinárodní sociologií nadále zůstávají téměř nedotčeným výzkumným tématem (výjimkou je Nešpor 2017).

\section{Bláha a Obrdlík na cestě $\mathrm{k}$ americké sociologii}

Na samém počátku př́prav své knihy The Makers of Sociology, v prosinci 1933, požádal Eubank několik kolegů dobře obeznámených s evropskými poměry, aby mu doporučili, které významné postavy evropské sociologie má kontaktovat. $\mathrm{V}$ Eubankově fondu se zachovaly zápisy s odpověd’mi Howarda P. Beckera, Herberta Blumera, Pitirima A. Sorokina, Theodora Abela a Louise Wirtha. Bláhu navrhl Wirth, kterému nedávno v Bláhově Sociologické revui 
vyšel informativní text o uplatnění absolventů sociologie (Wirth 1933). Sorokin znal Bláhu daleko lépe, ale ve svých doporučeních se omezil skoro jen na ruskou sociologii. Žádný další český sociolog nebyl uveden ani na jednom seznamu. ${ }^{6}$

Bláhova cesta $\mathrm{k}$ americké sociologii byla poměrně dlouhá. Ze zahraničních tradic, které jej ovlivnily v rané fázi jeho vývoje, byly nejdůležitější sociologie francouzská a německá. Ve svém přehledu aktuálních sociologických směrů z let 1912 a 1913 věnoval nejvíce místa západo- a středoevropské sociologii, hlavně francouzské (Émilu Durkheimovi, ale také Gabrielu Tardeovi a jeho následovníkům). Důkladně charakterizoval i sociologické teorie Lestera Warda a Franklina H. Giddingse, první jako čistý sociologický subjektivismus, druhou jako umírněný objektivismus (Bláha 1912, s. 298-299, 398-400; Bláha 1913). Nešlo však o doklad hluboké znalosti americké sociologie, oba tito autoři byli mezi českými zájemci o sociologii na počátku 20. století docela dobře známi. Ještě ve druhé dekádě století, kdy vydal svou monografii Město (1914), vycházel Bláha téměř výhradně ze středoevropské a francouzské tradice (také Janák 2006, s. 24).

$\mathrm{V}$ dalších letech se však o americkou sociologii začal zajímat mnohem více, důvodem pravděpodobně byl jak její rapidní růst, tak také významná úloha USA při vzniku samostatného Československa. Bláha nezi̊stal pozadu za mladšími českými sociology meziválečné doby v poznání, že sociologové ze zámoří převzali od Francouzů vedení v organizačním a stále více i v obsahovém rozvoji oboru. Svůj kritický realismus, myšlenku vyvážené středové pozice mezi objektivismem a subjektivismem, považoval za blízký převládajícímu stanovisku americké sociologie, která podle jeho vlastní formulace dokázala náležitě docenit „i faktora individuálního i sociálního“ a byla si vědoma „všech částečných podmíněností sociálního jevu“. Pokud šlo o využití sociologie v praxi, Bláha se dokonce domníval, že „America docet“ zbytek světa (Bláha 1929, s. 411, 413, 414). Přibližným ukazatelem rozložení Bláhova zájmu o zahraniční sociologické tradice jsou počty jeho publikací v Sociologické revui. Z celkem 393 textů věnoval americké sociologii plných 40 (přes $10 \%$ ), následovala sociologie polská (7,5 $\%$ ), německá a francouzská (obě cca $2,5 \%$ ). ${ }^{7}$ Větší pozornost odborné produkci USA než jakékoli jiné národní sociologie věnoval i Obrdlík ( $29 \%$, na druhém místě francouzské $13,5 \%$ ) a druhý Bláhův redakční asistent Bruno Zwicker (19 \%, německé 14,5 \%). Naopak vliv americké sociologie - ve smyslu odkazů na americkou literaturu a přejímání idejí z ní - není nijak výrazný v Bláhových monografiích z 20. a 30. let. Zato se zřetelně projevuje v syntetické práci Sociologie z konce 40. let, která, jak známo, mohla vyjít až mnohem později (Bláha 1968).

Začátkem 30. let Bláha nebyl mezi americkými sociology neznámou postavou. Vděčil za to nejen několika svým článkům vydaným ve francouzských a německých časopisech, které si tehdy uměla přečíst $\mathrm{i}$ řada elitních amerických sociologů, ale také cílevědomému pěstování amerických konexí. Bláha a později i Obrdlík usilovali o navázání kontaktu s etablovanými americkými sociology a vyhledávali americké publikační možnosti. Často sehrály

6 „European sociologists“, strojopisné záznamy datované 27. až 31. 12. 1933, kt. 11, Eubank Papers, University of Chicago.

7 Texty byly počítány bez ohledu na typ (nejčastějším typem byla recenze), kódování podle názvu. Za podklad posloužilo elektronické vydání Sociologické revue (Nešpor a Kopecká 2011). 
důležitou zprostředkovatelskou roli už existující konexe, především s osobami původem z Československa nebo Evropy (což byli i Sorokin, Becker a Wirth).

Bláha a Obrdlík se také snažili rozšírit svůj sociální a symbolický kapitál členstvím v amerických vědeckých organizacích. V březnu 1932 Bláha poslal do Chicaga tehdejšímu tajemníkovi Americké sociologické společnosti (ASS) Blumerovi žádost o přijetí mezi členy a o zasílání American Journal of Sociology (AJS). ${ }^{8}$ Neodmítali však ani př́ležitost stát se členy spíše popularizačních spolků (,fraternities“) sdružujících sociology a další sociální vědce. V prosinci 1933 byl Bláha na základě doporučení česko-amerického sociologa Josefa S. Roučka zvolen čestným členem Americké honorární společnosti pro sociální vědy Pi Gamma $\mathrm{Mu}^{9}$ a jejím čestným členem se nejspíše o něco později stal také Obrdlík. Oba brzy využili možnosti publikovat své texty v časopise této organizace Social Science (Obrdlík 1935; Bláha 1936). V té době nešlo o zcela neprestižní záležitost, jak ukazuje fakt, že předsedy Pi Gamma Mu ve 30. letech byli respektovaní sociologové Charles A. Ellwood a Edward A. Ross, zatímco agilní Sorokin se koncem téže dekády stal jejím místopředsedou. Obrdlík byl navíc členem jiné honorární společnosti, v tomto př́ipadě určené výhradně pro sociology, Alpha Kappa Delta, ${ }^{10}$ kterou v roce 1920 založil vedoucí katedry sociologie na Univerzitě jižní Kalifornie Emory S. Bogardus a v jejímž vedení ve 30. letech působili další významní sociologové Luther L. Bernard nebo Read Bain, mezi členy pak patřil také Eubank.

\section{Eubank a štěpení v americké sociologii meziválečného období}

Earle E. Eubank nepatří ke známým postavám meziválečné americké sociologie a asi tím jediným, co jej dodnes udržuje v povědomí historiků sociologie, je jeho putování od jednoho evropského sociologa $\mathrm{k}$ druhému v roce 1934, z něhož se zachovaly cenné dokumenty zpracované v Käslerově knize. Ve své době to však byl poměrně úspěšný a vlivný sociolog. Doktorát ze sociologie získal na Chicagské univerzitě u Roberta E. Parka (1916), od roku 1921 až do své smrti byl profesorem a současně vedoucím katedry sociologie na univerzitě v Cincinnati. Eubank patřil do řady významných sociologických sítí. Byl členem ASS, členem redakční rady AJS (1933-1945) a Bogardusova časopisu Sociology and Social Research, od vzniku American Sociological Review (ASR) v roce 1936 spolupracoval i s tímto časopisem (Käsler 1991, s. 6-13).

Eubank podobně jako mnozí jiní univerzitní sociologové své generace získal doktorát v Chicagu, nepatřil však k ,chicagské škole“ 20. a 30. let, ale spíše do opačného tábora. V první polovině 30 . let se v americké sociologii souběžně vyhrotily dva spory. První spor odděloval bohatou a dominantní chicagskou sociologii od jiných center oboru a od periferních institucí, jako byly malé colleges, nabízející pouze bakalářskou výuku. V druhém sporu se střetávali stoupenci objektivistické empirické sociologie, skeptičtí jak k filozofickým spekulacím, tak k sociálnímu aktivismu, s antiscientistickými představiteli sociologické teorie,

\footnotetext{
8 Dopis I. A. Bláha - Herbert Blumer 20. 3. 1932, kt. 1, fond Bláha, AV ČR, Praha.

9 Dopis Leroy Allen (výkonný tajemník Pi Gammna Mu) - I. A. Bláha 19. 1. 1934, fond Bláha, MU Brno.

10 CV Antonín Obrdlík, 1940?, kt. 4, Eubank Papers, University of Chicago.
} 
sociální filozofie a sociálního reformismu. Diferenciace věcných postojů a propletenost osobních vztahů byly přirozeně velmi komplikované, ale zjednodušeně se dá říci, že př́slušné strany obou sporů se nikoli nevýznamnou měrou překrývaly, ač se dvěma výhradami: chicagští sociologové 1. nebyli zdaleka všichni scientisticky orientovaní a 2. měli své spojence na jiných katedrách po celé zemi. Mezi jejich oponenty zase figurovalo nemálo chicagských absolventů, kteř́i odešli na jiné univerzity. Chicago ve sporu reprezentovali Ernest W. Burgess, William F. Ogburn nebo H. Blumer, s nimi spojený scientismus pak např́klad George A. Lundberg. Heterogennější skupinu jejich protivníků tvořili sociologové starší generace, obecně více naklonění sociální filozofii a reformismu, někteří objektivisté podporující sociální angažovanost sociologie, teoretici různého zaměření a protestantští sociální aktivisté. Vedoucími postavami byli Ellwood a Bernard, dále do protichicagské aliance patřili např́klad teoretici Becker (stejně jako oba předchozí sám chicagský absolvent) a Sorokin nebo ze starší generace Ross. ${ }^{11}$ Pro českou sociologii významný Sorokin sice ve sporu mezi scientisty a sociálními filozofy zaujímal spiše střední pozici (viz níže), ale jeho vztahy s chicagskou sociologií byly na odborné i osobní rovině velmi nepřátelské (Nichols 1996, s. 63-64). Někteř́ další významnější sociologové nestáli jednoznačně na jedné ani druhé straně sporu, protože sdíleli část svých zájmů s jednou i druhou skupinou - např́klad mimochicagští a scientisticky orientovaní Bogardus a F. Stuart Chapin. Hluboký konflikt přinesl svůj nejtrvalejší konkrétní výsledek v roce 1936, kdy se ASS rozloučila s chicagským $A J S$, který do té doby plnil roli jejího oficiálního časopisu, a nahradila jej nově založeným ASR (Bannister 1987, s. 189-214; Turner a Turner 1990, s. 58-65; Balon 2011, s. 45-62). Nekonfliktní a uměřeně ambiciózní Eubank měl pravděpodobně s chicagskými kolegy dobré osobní vztahy. Avšak ve velkém sporu uvnitř oboru v polovině 30 . let se jako sociolog, u nějž se zájem o teorii doplňoval se sociálním aktivismem, ocitl na straně protichicagské a protiscientistické aliance po boku Ellwooda, Sorokina a dalších.

Eubank pro Bláhu a zejména pro Obrdlíka představoval cenného pomocníka při pronikání do americké sociologie. Jestliže však, jak se ukázalo na přelomu 30. a 40. let, kdy se marně snažil Obrdlíkovi najít v USA stálé akademické místo, jeho možnosti v tomto směru měly své jasné meze, nebylo tomu tak jen proto, že nepůsobil na nejprestižnější univerzitě a nedosáhl na nejvyšší profesionální pozice, ale také - samozřejmě vedle vnějších faktorů, jakým byla zejména záplava evropských exulantů v USA - kvůli popsané polarizaci americké sociologie. To však neznamenalo, že Eubank byl zcela bez vlivu. Krátce po založení $A S R$ napomohl tomu, že se Obrdlík stal „československým korespondentem“ tohoto časopisu, ${ }^{12}$ a to v konkurenci s Roučkem, který v USA pobýval mnohem delší dobu. Obrdlík díky tomu publikoval hned v prvním a druhém ročníku $A S R$ dva krátké přehledové texty o dění v československé sociologii, z toho jeden ve spolupráci se Zwickerem (Obrdlík 1936a; Obrdlík a Zwicker 1937). Přátelské spojenectví s brněnskými sociology bylo užitečné i pro Eubanka.

11 Právě tito sociologové se angažovali jako hodnostáři výše zmíněných čestných společností pro sociální vědy.

12 Dopis Antonín Obrdlík - Earle E. Eubank 23. 1. 1936; dopis Eubank - Obrdlík s přiloženou kopií části dopisu Eubank - Frank H. Hankins (šéfredaktor ASR) 31. 1. 1936, kt. 4, Eubank Papers, University of Chicago. 
Už v době mezi prvním dopisem Bláhovi a svou návštěvou Brna byl jmenován dopisujícím členem Masarykovy sociologické společnosti (MSS), ${ }^{13}$ přičemž to byl právě Obrdlík, kdo vytvoření kategorie zahraničního dopisujícího člena v MSS navrhl (Chalupný 1935, s. 88).

\section{Meziválečná česká sociologie, IIS a silové pole mezinárodní sociologie}

Současně s národními sociologiemi vznikala v 19. století také sociologie mezinárodní, jejíž jedinou organizační základnu až do druhé světové války tvořily instituce založené v Paříži francouzským sociologem René Wormsem: časopis Revue Internationale de Sociologie (RIS) (1893) a Mezinárodní sociologický institut (1893/1894). Worms byl plodný autor, ale v literatuře převládá názor, že pro dějiny sociologie byl významný jen jako organizátor. Jeho působení vedlo ke vzniku volně sdružené skupiny, kterou Terry Nichols Clark ve svých dějinách rané francouzské sociologie výstižně nazval „mezinárodními sociology“. Skupina, jejíž členové byli podobně jako Worms spíše eklektického zaměření a která postrádala výjimečnou vědeckou osobnost, se nacházela $\mathrm{v}$ opozici ke dvěma konkurenčním skupinám: katolické leplayovské škole a durkheimovské „objektivistické“ sociologii. Sám Durkheim tvořil naprostou výjimku mezi významnými sociology své doby tím, že se členem IIS nikdy nestal. Celá durkheimovská škola byla vůči Wormsovi a jeho organizačním aktivitám zdrženlivá až nepřátelská (Heilbron 2015, s. 72-91; Clark 1973, s. 147-154; Cuin a Gresle 2004, s. 76-88).

IIS byl od počátku organizován spíše jako čestná vědecká akademie než vědecká společnost $\mathrm{v}$ dnešním smyslu. Jeho členstvo tvořili rádní a prridružení členové, kteří se co rok až tři scházeli na kongresech. Institut měl čestného předsedu a až tři místopředsedy, ale skutečné řízení spočívalo v rukou generálního tajemníka, kterým byl po mnoho let sám Worms. Po jeho smrti v roce 1926 se generálním tajemníkem stal Gaston Richard, původně Durkheimův př́vrženec, který se však vyvinul v jednoho z nejsilnějších kritiků durkheimovské školy. Po jeho boku se brzy vypracoval do pozice hlavního „tahouna“ institutu další francouzský sociolog Guillaume-Léonce Duprat, který byl od roku 1922 profesorem na ženevské univerzitě. Duprat měl v letech 1927-1937 na IIS rozhodující vliv jako jeho místopředseda a generální tajemník (Clark 1973, s. 222-226; Heilbron 2015, s. 94-95; Cuin a Gresle 2004, s. 142-143). Snažil se posílit mezinárodní prestiž institutu a svoje postavení jako šéfa exekutivy transformací IIS na sdružení či federaci národních sociologických společností a velmi mu záleželo na tom, aby do IIS vstoupila velká a bohatá ASS. Američtí sociologové byli v IIS zastoupeni v počtu asi čtyřiceti osob a Duprat si vypěstoval velmi dobré vztahy s Ellwoodem, Bernardem, Sorokinem i dalšími. Nebylo však málo ani těch Američanů - zejména na Chicagské univerzitě -, pro které francouzskou sociologii představovali jen durkheimovci. Dva Dupratovy pokusy o připojení ASS k IIS, při nichž mu jako jeden z amerických spojenců pomáhal i Eubank, sám přidružený člen institutu, zkrachovaly na společném odporu durkheimovské školy a chicagských sociologů. Ve druhé polovině 30. let situaci v IIS pro Duprata ještě více zkomplikoval rostoucí vliv sociologů sympatizujících $\mathrm{s}$ fašismem, jejichž neformální hlavou byl italský statistik Corrado Gini. Na 13. kongresu IIS konaném v roce 1937 v Paříži Gini a jeho spojenci 
dosáhli Dupratovy rezignace na všechny výkonné funkce. Prezidentem institutu byl zvolen žák Marcela Mausse, právník, sociolog a etnolog René Maunier (Bannister 1992, s. 185; Turner 2010, s. 171-174; Rol 2011, s. 34-36).

Česká sociologie byla až do roku 1918 v IIS zastoupena prakticky jen reprezentativní osobností Tomáše G. Masaryka. V meziválečném období členství a aktivita českých sociologů v IIS postupně narůstaly, nejvyšší byly před závěrem 30. let. V roce 1923 se přidruženými členy IIS stali Bláha, Chalupný a Břetislav Foustka (Chalupný 1935, s. 80-81), na konci 30. let byli řádnými členy Beneš, Bláha a Chalupný a členy přidruženými Foustka, Král, J. L. Fischer, František Modráček a Anton Štefánek. Chalupný (1934-1935) a Bláha (1936-1937) dokonce působili jako místopředsedové institutu. Přední čeští sociologové také občas publikovali v RIS, nejvíce Bláha. Na rozdíl od Američanů byla MSS možnosti federativního přidružení $\mathrm{k}$ IIS nakloněna velmi př́znivě a stala se členem institutu už během prvního kola Dupratovy iniciativy v roce 1930 (Chalupný 1935, s. 88; Nešpor a kol. 2014, s. 138). Pražští sociologové byli v navazování kontaktů v IIS za brněnskými kolegy (kteří měli rozhodující slovo v MSS) pozadu, zpoždění doháněli až koncem 30. let. Na pařížském kongresu v roce 1937 byla přijata za člena IIS jejich Společnost pro sociální bádání (Ullrich 1938-1939, s. 88).

IIS, jeho spojenci a odpůrci tvořili předválečnou mezinárodní sociologii, která, jak už naznačil výklad o vývoji uvnitř institutu, byla diferenciovaná podle dvou základních štěpení. Zastánci novějšího pojetí sociologie jako striktně empirické, pozitivní a „objektivistické“ vědecké disciplíny (Durkheim a jeho žáci, chicagská škola) se dostali do konfliktu s představiteli staršího pojetí, v němž zůstával velký prostor pro sociální filozofii a eticko-politické reformní cíle (Worms, Duprat, Ellwood). Druhé štěpení oddělovalo od konce 20. let obhájce fašistických diktatur od různě politicky orientovaných odpůrců fašismu a nacismu. Obě štěpení se částečně prékrývala, nebot' mezi zastánci scientismu a objektivismu v Evropě i USA se nacházeli tací, pro které byl fašismus pro svou domnělou vyšší výkonnost ve srovnání s demokracií zajímavou alternativou modernity (Bannister 1992).

Představitelé české sociologie navazovali kontakty se zahraničními sociology a zaujímali v odborných otázkách pozice podobné jejich pozicím podle téže vnitřní logiky, která vytvářela polarizaci uvnitř IIS a v celé tehdejší mezinárodní sociologii. Každý ze dvou pólů štěpení v domácí sociologii, tedy brněnská a pražská sociologická skupina, se přiblížil jednomu z pólů mezinárodního štěpení. Bláha, Chalupný a brněnská sociologie tíhli k alianci, kterou tvořili Richard, Duprat, Ellwood a poněkud hưře zařaditelný Sorokin, a patřil do ní i Eubank. Pražští sociologové měli naopak blízko k chicagské škole, která byla americkým spojencem durkheimovců, tvořících ve Francii opozici proti Richardem a Dupratem vedenému IIS.

Čeští sociologové byli svědky převratu na pařížském kongresu v roce 1937. Osobně prítomni byli Bláha, Chalupný, Král, Ullrich a Machotka (Obrdlík svůj př́spěvek poslal). Je př́iznačné, že když Bláha o změnách ve vedení IIS referoval na stránkách Věstníku Československé akademie zemédělské, bylo to překvapeným tónem a bez jakéhokoli nadšení. Zároveň ale velmi přesně vystihl povahu prohlubujícího se štěpení uvnitř mezinárodní sociologie, když napsal, že na sjezdu se utkaly směr zaměřený „k syntetickému chápání společenských jevư“, jehož slabinou je spekulativnost, a směr „orientovaný spíše ke konkrétní a analytické sociologické práci“, jemuž hrozí sociografická deskriptivnost (Bláha 1937; Bláha 1996-2004: 134-135). Ullrich byl naopak ve své zprávě k Dupratovi a průběhu konference 
v jeho režii velmi kritický. Stranil novému předsedovi Maunierovi, kterého označil za spojku „mezi kongresu se vzdalující skupinou žáků Durkheimových a mezinárodním institutem“ (Ullrich 1938-1939: 84).

\section{Vzłah brněnské a pražské skupiny k hlavním frakcím mezinárodní sociologie}

Homologie mezi uspořádáním českého a mezinárodního sociologického pole se v odborných a politických pozicích, které čeští sociologové zaujímali, a v kontaktech, které navazovali, projevovala zřetelným, i když přirozeně ne zcela jednoznačným způsobem. To lze doložit na vztahu české sociologie $\mathrm{k}$ durkheimismu a jeho americkému spojenci, chicagské škole. I v rámci francouzské sociologie byl protiklad mezi skupinou „mezinárodních sociologü“ a durkheimovci na věcné rovině oslabován okolností, že mnozí představitelé IIS, mezi nimi i vedoucí postavy Richard, Duprat a Maunier, na Durkheima a jeho školu v různých ohledech navazovali (což ale naopak neplatilo). Také Bláhu Durkheimova sociologie silně ovlivnila, ale už od svého druhého pařížského pobytu v roce 1908 udržoval přátelské styky s Wormsem (Bláha 1996-2004, s. 31). Po jeho smrti vydal v České mysli nekrolog, ve kterém obhajoval Wormsův eklekticismus jako projev pružné a konciliantní povahy a označil jej za „dobrého znalce českých poměrư “ (Bláha 1926: 305). Vůči francouzské sociologii se Bláha ve svých publikacích, organizační činnosti i osobních kontaktech snažil zaujímat vyvážený postoj: ani čistý durkheimismus, ani zcela proti Durkheimovi (např. Bláha 1913; Bláha 1929, s. 408-411). V sociologické knihovně vydávané MSS vyšla s Bláhovou podporou, a dá-li se v tomto bodě věřit jeho pamětem a Chalupného zprávě, i z Bláhovy iniciativy, jak Durkheimova Pravidla sociologické metody (v roce 1926), tak Wormsův Úvod do studia lidské společnosti (1928) a údajně navrhoval k vydání také jednu z knih G. Richarda (Chalupný 1935, s. 84). Osobní a písemné kontakty Bláha navázal nejen s Wormsem a později Dupratem a jeho dcerou Jeanne Dupratovou, rovněž socioložkou, ale také s durkheimovci Célestinem Bouglém a Lucienem Lévy-Bruhlem (Bláha 1996-2004, s. 66). V Sociologické revui se tiskly články z durkheimovské i opačné strany (durkheimovec Bouglé, jeho žák Raymond Polin, „středový“ Maunier, antidurkheimovci Richard, Duprat). Ostatně jak Bouglé, tak i Richard a Duprat byli oficiálními zahraničními spolupracovníky Bláhovy revue.

Spř́ízněnost s mezinárodní aliancí odpůrců durkheimovské a chicagské sociologie se v brněnském časopise projevovala spíše ve výběru amerických příspěvků, mezi kterými s výjimkou již výše zmíněného drobného článku L. Wirtha produkty chicagské sociologie chyběly. Z amerických autorů v časopise nejvíce publikovali Sorokin, Becker a Eubank, jednou také Robert MacIver, tedy sociologové, kteří byli součástí opozice proti scientismu a chicagské dominanci (Bannister 1987, s. 196).

Také pražští rivalové brněnské sociologie Machotka a Ullrich byli ve svých začátcích ve 20. letech Durkheimem a francouzskou sociologií silně ovlivněni, ale brzy dospěli k závěru, že durkheimismus předběhla americká, a dokonce i německá sociologie, zejména sociologie skupin a sociální psychologie (podrobně např. Ullrich [1932] v odmítavé recenzi knihy jediného skutečného českého durkheimovce Antonína Uhlíře Sociologická idea). I když však od konce 20. let stále více hledali vzory pro vlastní sociologickou práci v USA, nadále se hlásili k durkheimovskému desideratu objektivistické vědecké sociologie. Další člen pražské 
skupiny, na Německo orientovaný Jan Mertl (pro změnu stoupenec objektivismu weberovského ražení), částečně podlehl vlivu Carla Schmitta a některých dalších autorů s fašistickou tendencí. Třebaže nebyl nekritickým př́iznivcem fašistického hnutí, podporoval autoritativní proměnu demokracie. Tím v české sociologii našlo odraz - tak jako v prvním př́ípadě nikoli mechanický, nýbrž intelektuálně zprostředkovaný a modifikovaný - druhé štěpení mezinárodní sociologie probíhající mezi stoupenci a odpůrci fašismu. Ve své zprávě z 12. kongresu IIS v Bruselu v roce 1935 se Mertl vyjádřil kriticky o Dupratovi, Ellwoodovi a také Dupratově hlavním německém partnerovi Leopoldu von Wiesem, v jejichž vystoupeních jej iritoval „duch staršího sociologického myšlení. Naopak se sympatiemi referoval o příspěvcích delegace italských sociologů, v níž vedle již postaršího Roberta Michelse dominoval Dupratův protivník Gini (Mertl 1935).

I když se různí členové pražské skupiny vydali různými cestami, z hlediska logiky rozdělení mezinárodní sociologie zaujímali konzistentní stanoviska: at' už spolu s durkheimovci a chicagskou školou nebo v koketérii se stoupenci fašismu, vždy proti Dupratovi a jeho mezinárodním spojencům v IIS, a to znamená i proti brněnské skupině. V pražských Sociálních problémech vyšlo několik recenzí na nový durkheimovský časopis Annales sociologiques od Krále a Ullricha a články durkheimovců Halbwachse a Antoine Meilleta, naopak nic od „mezinárodních sociologů“ z IIS. Na druhou stranu se však v Sociálních problémech neobjevil ani jeden článek od př́slušníků chicagské školy. Receptivita pražské skupiny vůči chicagskému vlivu se projevovala jinde, ve vlastních empirických výzkumech, zejména výzkumu poměštování pražského okolí (Musil 2012).

\section{Dva čeští rivalové stážují v USA}

Antonín Obrdlík a Otakar Machotka (1899-1970) shodně patřili k mladší generaci meziválečných sociologů, oba pobývali skoro ve stejnou dobu v USA jako stipendisté Rockefellerovy nadace, oba také nakonec do USA odešli natrvalo jako političtí emigranti. Jeden patřil $\mathrm{k}$ brněnské a druhý $\mathrm{k}$ pražské sociologické skupině, které si navzájem konkurovaly, a mezi oběma se v průběhu 30 . let vytvořila silná osobní rivalita. Okolnost, že tito téměř ideálnětypičtí reprezentanti hlavního štěpení $\mathrm{v}$ české sociologii měli srovnatelné americké zkušenosti, je dobrým důvodem ke srovnání jejich kontaktů v USA. Jestliže, jak už bylo na některých faktech ukázáno výše, mezi českou, mezinárodní a americkou sociologií existovala přibližná strukturní homologie, pak by se antagonismus mezi brněnskou a pražskou sociologií měl projevit také tím, že Obrdlík i Machotka v Americe navázali kontakty s př́slušníky odpovídajících vzájemně antagonistických skupin. Taková korespondence nemusí být dokonalá, ale měla by být zřetelná. Opatrněji je třeba zkoumat související otázku, zda homologie mezi uspořádáním sociologického pole v Československu a USA mohla mít vliv na rozdílné kariérní dráhy a odborný úspěch těchto dvou sociologů. Kariérní výsledky totiž mohly být ovlivněny i některými specifickými okolnostmi, které srovnání komplikují. Například každý měl jiné odborné zájmy (Machotka: rodina, město, sociální psychologie; Obrdlík: venkov, demokracie, mezinárodní politika) (Nešpor a kol. 2014, s. 181-183, 240-245; Janák 2014).

O průběhu rockefellerovských stipendijních pobytů Obrdlíka a Machotky (oba jeli s manželkami a oba byli v době stáže ještě bezdětní) podávají základní informace jejich osobní 
záznamy v kartotéce stipendistů RF. ${ }^{14} \mathrm{~V}$ Americe se těsně minuli. Manželé Machotkovi pobývali v USA od října 1934 do poloviny záŕí 1935, Antonín a Soňa Obrdlíkovi od začátku října 1935 do září 1936, poté jim bylo stipendium prodlouženo a pobývali dalších deset měsíců v západní Evropě. Zde se zaměříme na otázku, kteří američtí sociologové hráli v průběhu jejich stáží významnější roli.

Obrdlík byl od začátku své akademické kariéry závislý na svém tchánovi a vědu opustil dř́ive, než se z této závislosti mohl vymanit. Jeho pozice v mezinárodní sociologické komunitě byla předurčena pozicí, kterou zaujímal Bláha. Už Obrdlíkovy první větší publikace ukazují, na které straně předělu v mezinárodní sociologii se nacházel. Čtenářům České mysli, na jejíchž stránkách právě proběhl domácí spor o objektivismus, v němž nesociologové od sociologie požadovali více aktivismu a sociologové bránili její vědeckost (Nešpor a kol. 2014, s. 149), představil bez známek zásadního nesouhlasu argumenty Ellwoodových Methods in Sociology (1933), tedy knihy, která přinesla nejtvrdší kritiku „behavioristické sociologie“, stále oblíbenější u mladší generace amerických sociologů (Obrdlík 1934a). Napsal také podobně nekritickou studii o francouzském antidurkheimovském sociologu Richardovi (Obrdlík 1934b) a pravděpodobně se podílel i na českém vydání tří Richardových článků v Sociologické revui. $\mathrm{Z}$ několika desítek recenzí, které publikoval v brněnském časopise, se pouze tři týkaly prací durkheimovců Bouglého a Halbwachse a žádná chicagské školy nebo amerických scientistických sociologů.

Za udělení rockefellerovského stipendia Obrdlíkovi se údajně přimluvil sám Sorokin, významný člen mezinárodní aliance, do které patřil Bláha. ${ }^{15}$ Obrdlík se podle osobní karty stipendisty uchované $\mathrm{v}$ archivu RF chtěl v USA věnovat výzkumu politického vůdcovství v demokracii. Jako hlavní hostitelské pracoviště si vybral Chicagskou univerzitu, kde hodlal spolupracovat se „,sociology sdruženými kolem American Journal of Sociology“. Byl ve styku s politology Charlesem E. Merriamem a Haroldem Laswellem, zatímco o kontaktech, nebo dokonce spolupráci s Parkem, Burgessem a dalšími chicagskými sociology není na osobní kartě zmínka. Podle jiného pramenu z RF sice Obrdlík asi měl jistý kontakt s Ogburnem a Blumerem, ${ }^{16}$ ale nezdá se, že by s některým z místních sociologů navázal hlubší profesní nebo osobní vztahy. V Chicagu setrval pouze dva a půl měsíce, další čtyři měsíce strávil na univerzitách v New Yorku. Zde byl v kontaktu s Henry P. Fairchildem, tehdejším prezidentem ASS, a s politologem Charlesem Hodgesem, působícími na Newyorské univerzitě, a se sociology MacIverem a Robertem Lyndem z Kolumbijské univerzity. Konečně od dubna do srpna 1936, tedy dalších pět měsíců, stážoval na Harvardu, kde jeho hlavním tutorem byl Sorokin, toho času ovšem na sabbaticalu. Obrdlík byl ve styku se dvěma dalšími harvardskými profesory, historikem Williamem Yandellem Elliottem a politologem německého původu Carlem Joachimem Friedrichem. Lze shrnout, že v Chicagu se Obrdlík neuchytil a na dalších

14 (FA426), fond RF, RAC, New York.

15 Dopis Stacy May (druhý zástupce ředitele divize sociálních věd RF) - Earle E. Eubank 2. 8. 1939, kt. 4, Eubank Papers, University of Chicago.

16 Dopis Stacy May - Earle E. Eubank, viz předchozí poznámku. 
univerzitách byl $\mathrm{v}$ kontaktu spiše se sociology $\mathrm{z}$ antiscientistického tábora nebo $\mathrm{s}$ podobně orientovanými politology.

Průběh o rok dřívější Machotkovy stáže byl v některých důležitých ohledech velmi odlišný. V pramenech není uvedena informace o tom, jestli Machotku také doporučil Sorokin, nebo, což je pravděpodobnější, některý pražský spolupracovník RF (oficiálním českým poradcem nadace pro udílení stipendií ve společenských vědách byl pražský národohospodář Josef Macek). Podle záznamů RF strávil Machotka na Chicagské univerzitě celý první půlrok svého stipendia, intenzivně se účastnil několika seminářů a s Ernestem Burgessem spolupracoval na výzkumu rodin $\mathrm{v}$ chicagské aglomeraci. V druhé polovině stáže pobýval na Univerzitě jižní Kalifornie v Los Angeles, kde byl v kontaktu s Bogardusem, Erlem F. Youngem a Clarence M. Casem, a nakonec krátce na Newyorské univerzitě, kde docházel na přednášky Frederica M. Thrashera (viz také Machotková 2001). V̌̌ichni jmenovaní byli spojení s Chicagem jako jeho absolventi nebo bývalí učitelé, a třebaže např́klad Bogardus měl s chicagskou katedrou různé spory, patřili v poli americké sociologie do chicagského tábora nebo mezi nevyhraněné. Kontakty obou českých stipendistů a průběh jejich stáží odpovídají tezi o jejich strukturální afinitě $\mathrm{k}$ př́slušným antagonistickým skupinám $\mathrm{v}$ americké sociologii.

Je však třeba se zastavit aspoň u jednoho faktu zdánlivě protiřečícího danému očekávání, a to dobrých vztahů P. Sorokina nejen s brněnskými, ale také pražskými sociology. Sorokin na začátku své kariéry v Rusku vyšel $\mathrm{z}$ teorie reflexů a behaviorismu a ještě ve 20. letech v USA sám sebe považoval za představitele empirické metody, ale od následující dekády se začal od modelu pozitivistické sociální vědy stále více vzdalovat, aniž by ovšem ze svého rejstř́ku modalitu exaktního empirického výzkumu zcela vypustil (Balon 2011, s. 72-73; Nichols 1996). V americkém a současně i mezinárodním konfliktu mezi filozofujícími teoretiky a scientisty se proto nacházel blíže pomyslného středu než většina ostatních účastníků. Také jeho politické postoje představovaly nesourodou kombinaci progresivních a konzervativních myšlenek, díky které jej mohli snáze akceptovat představitelé velmi odlišných politických směrů. Toto specifické umístění v polích zaujímání vědeckých i politických pozic tvořilo strukturální pozadí za jeho zvolením předsedou IIS po Ellwoodovi v nejnapjatějších letech 1936-1937, a tím i za skutečností, že předsedal osudovému pařížskému kongresu v roce 1937 (Turner 2010, s. 173). Sorokinovo středové či přechodné postavení se odráželo také v jeho vztazích s českými sociology. Sorokin a Bláha byli spráteleni od doby Sorokinova exilového pobytu v Praze v letech 1922-1923, pravidelně spolu korespondovali a Sorokin poměrně často publikoval v Sociologické revui (Bláha 1996-2004, s. 55, 134). Nebyl to však exkluzivní vztah, dobré kontakty se Sorokinem navázala také pražská skupina, i když o něco později. Sorokinovy Sociologické nauky prritomnosti vyšly v roce 1936 česky v překladu Ullrichovy manželky Blaženy Ullrichové a v Ullrichově pečlivé úpravě. O rok později se Král a Ullrich (Machotka nejspíš také) na kongresu IIS v Paříži poprvé se Sorokinem osobně setkali a na toto setkání navázala nejen občasná korespondence, ale také Sorokinova pomoc Ullrichovi se získáním místa na univerzitě v egyptské Alexandrii po jeho emigraci v roce 1948 (viz také Nešpor 2017, s. 751). Přinejmenším až do konce 30. let však měl Sorokin stále ještě bližže k Bláhovi a brněnské sociologii. Nejlépe to dokládá role, kterou sehrál ve známém sporu o Obrdlíkovu habilitační práci Povoláni a veřejné blaho (1937) mezi Obrdlíkem a Bláhou na jedné straně a Machotkou a Králem na straně druhé (Nešpor a Janák in Nešpor a kol. 2014, 
s. 181-183). Sorokin Obrdlíkovu problematickou knihu „zachránil“ velmi pochvalným dobrozdáním (Sorokin 1938), o které jej diskrétně požádali Bláha a Obrdlík prostřednictvím Josefa Roučka a jehož obsah a formu posléze ve svém dopisu pomáhal „doladit“ sám Obrdlík. ${ }^{17}$

\section{Umístění v sociologickém poli jako faktor pokračování kariéry po emigraci}

Antonín Obrdlík ve druhé polovině 30 . let publikoval v USA několik krátkých recenzí ve velmi prestižních časopisech (AJS, ASR, Annals of the American Academy of Political and Social Science), dvě již zmíněné zprávy o československé sociologii v $A S R$ a dva články v časopisech Social Science a Rural Sociology (Obrdlík 1935, 1936b). Lze se domnívat, že za těmito publikacemi stál Eubank, možná Sorokin. Eubank také pravděpodobně Obrdlíkovi pomohl publikovat jeho jediný článek v prvotřídním časopise (AJS), který pojednával o šibeničním humoru v Protektorátu Čechy a Morava (Obrdlík 1942). Po Obrdlíkově př́íchodu do USA začátkem roku 1940 se Eubank všemožně snažil nastartovat jeho americkou akademickou kariéru. Obrdlík však po dvou letech strávených učením na Hiram College a Ohio Wesleyan University, menších liberálních colleges v Ohiu, nastoupil na československé vyslanectví ve Washingtonu. $\mathrm{K}$ akademické profesi se vrátil už jen krátce a na částečný úvazek ve dvou poválečných letech, která strávil opět v Československu. V roce 1947 definitivně emigroval zpátky do USA a po celou svou další pracovní kariéru působil na střední úrovni řízení u OSN (Obrdlík 1970; Janák 2014).

Mezi českými meziválečnými sociology mladší generace měl bezesporu právě Obrdlík nejlepší předpoklady pro úspěšnou univerzitní dráhu v USA (konkurovat mu mohl pouze Machotka - Nešpor 2017: 738). Měl na tehdejší poměry velmi důkladnou akademickou průpravu, výborné jazykové vybavení, dostatek publikací nejen v češtině, ale i v angličtině a v neposlední řadě patronát Bláhy, Eubanka a Sorokina. Přesto jeho akademická kariéra v USA brzy skončila. Úspěšné obnovení kariéry po emigraci závisí na nejrůznějších faktorech, k nimž patří osobní charakteristiky jednotlivce, povaha a rozsah jeho sociálního kapitálu i vnější strukturální podmínky (Fleck 2015, s. 406-425). Obrdlík se v USA akademicky neetabloval, přestože řada faktorů hrála ve prospěch pokračování jeho akademické dráhy, do níž navíc ve 30. letech investoval značné množství času a energie. Také Machotka skončil v americké emigraci, ale ač byl starší, přišel až v roce 1948 a do té doby strávil v USA mnohem kratší dobu než Obrdlík, podařilo se mu získat stálé profesorské místo na solidní Harpur College (později State University of New York, Binghamton). Rozhodující pomoc mu poskytl E. W. Burgess, jeho tutor během rockefellerovské stáže na Chicagské univerzitě před válkou, a další chicagští sociologové (Nešpor 2017, s. 738-744).

Eubank zemřel v roce 1945 a s ním Obrdlík ztratil svého největšího podporovatele. Sorokinův vliv v americké sociologii byl na sestupu už od konce 30. let, kdy se stal zjevným jeho odklon od scientismu (Nichols 1996, s. 53-57). Př́ícin, pro které Obrdlík v USA v akademické dráze nepokračoval, bylo jistě více. Jedno z možných vysvětlení je třeba hledat

17 Dopis Antonín Obrdlík - Pitirim A. Sorokin 7. 5. 1938, kt. 20, Sorokin Papers, University of Saskatchewan. Výklad v tomto odstavci čerpá ze Sorokinovy prrijaté korespondence s Obrdlíkem, Králem a Ullrichem (kt. 17, 20, 23 tamtéž). 
i v Obrdlíkově umístění v poli meziválečné české sociologie a v jemu odpovídajícím umístění ve strukturách mezinárodní a americké sociologie. Kontakty získané pod Bláhovou tutelou byly ve 30 . letech velmi užitečné, protože podobně zaměření sociologové starší a střední generace zaujímali vlivné posty v řadě národních sociologií včetně USA. Po druhé světové válce však mezinárodní sociologická aliance, $\mathrm{k}$ níž Bláha patřil, již prakticky neexistovala a celá mezinárodní sociologie se nacházela v procesu strukturální proměny. Obrdlík se ocitl v izolaci a př́liš daleko od nového mainstreamu americké sociologie. Naopak Machotkovi mohly jeho staré chicagské kontakty po emigraci do USA pomoci, nebot' mnohostranná chicagská sociologie prošla proměnami 30. a 40. let bez většího oslabení (Turner a Turner 1990, s. 109-110; Balon 2011, s. 67-71).

\section{Závěr}

Předčasný konec Obrdlíkovy akademické kariéry v USA tedy zřejmě neměl své příčiny jen v rovině osobní a situační, ale přispěla $\mathrm{k}$ němu i jeho ( $\mathrm{v}$ dané době) nevýhodná pozice v poli americké sociologie předurčená homologií mezi národními sociologickými poli v rámci mezinárodní sociologie. Srovnání amerických konexí Obrdlíka a Machotky přineslo výsledky v souladu s očekáváním, že členové brněnské a pražské školy navazovali kontakty - a pomocí těchto kontaktů pak získávali další sociální, kulturní a symbolický kapitál - mezi př́slušníky podobně strukturálně umístěných skupin. Srovnání jimi zaujatých odborných pozic ve vztahu k pozicím zaujímaným jejich strukturálními spojenci by patrně dopadlo o něco méně jednoznačně. Machotkův intelektuální vývoj bývá interpretován tak, že se už na konci 30. let začal od scientismu, který odpovídal strukturálnímu umístění pražské skupiny v rámci české a zprostředkovaně i mezinárodní sociologie, odklánět směrem ke kvalitativní sociální psychologii (např. Nešpor 2017, s. 745-750). Je však třeba zmínit, že se Machotka aspoň na začátku svého amerického exilu, a tedy $\mathrm{v}$ situaci, kdy bylo $\mathrm{v}$ jeho zájmu zaujetím odpovídající odborné pozice stvrdit svou sociální pozici spojence chicagské sociologie, právě v chicagském $A J S$ přihlásil $\mathrm{k}$ naturalistickému, byt' částečně diferencujícímu pojetí sociologie (Machotka 1949). V Obrdlíkově publikační produkci od konce 30. let, která se převážně orientovala na politickou vědu a navíc byla stále méně početná, je možné aspoň v náznaku pozorovat ovlivnění objektivismem, který prosazoval chicagský politolog Merriam a další zastánci behavioristického prrístupu v politologii (Obrdlík 1946). Vývoj obou sociologů se sice zdá být $\mathrm{v}$ rozporu $\mathrm{s}$ tezí o homologii, ale spíše pomáhá přesněji vymezit její časovou platnost. Proměnu zastávaných pozic a stejně tak i přesun ze sociologie do jiného oboru (v obou př́padech) lze chápat jako individuální důsledky upadající životnosti nejen mezinárodní sociologické aliance, do níž patřil Obrdlík, ale celého meziválečného uspořádání mezinárodní sociologie, které dosáhlo vrcholného bodu svého rozvoje na pařǐžském kongresu IIS v roce 1937. V meziválečných letech byli Obrdlík i Machotka mladými začínajícími akademiky a jako takoví byli definováni spíše tím, kde $\mathrm{v}$ oborovém poli byla umístěna skupina, $\mathrm{k}$ níž patřili, než svými vlastními odbornými pozicemi. $\mathrm{V}$ jejich intelektuálním vývoji muselo dříve nebo později dojít k osamostatnění (žretelně u Machotky, u Obrdlíka jen v počátcích), ale vztah intelektuální dráhy jednotlivce k původní disciplinární struktuře, ze které vyšel, je již námětem pro jiné pojednání. 


\section{Archivní fondy}

Eubank, Earle Edward Papers, 1925-1946. Special Collections Research Center, University of Chicago. Chicago, IL, USA.

Fond Bláha Inocenc Arnošt, prof. PhDr. Archiv Masarykovy university. Brno.

Fond Bláha Arnošt Inocenc. Masarykův ústav a Archiv AV ČR. Praha.

Pitirim A. Sorokin Manuscripts and Papers. Special Collections Department, University Library, University of Saskatchewan, Kanada.

Rockefeller Foundation (RF). Rockefeller Archive Center. Sleepy Hollow, New York, USA.

\section{Literatura}

BALON, Jan. 2011. Sociologie v USA: Historické kontextualizace. Praha: Sociologické nakladatelství.

BANNISTER, Robert C. 1987. Sociology and Scientism: The American Quest for Objectivity, 18801940. Chapel Hill: University of North Carolina Press.

BANNISTER, Robert C. 1992. „Principle, Politics, Profession: American Sociologists and Fascism, 1930-1950.“ Pp. 172-213 in Dirk KÄSLER a Stephen P. TURNER (eds.). Sociology Responds to Fascism. Abingdon: Routledge.

BLÁHA, Inocenc Arnošt. 1912. „O některých směrech současné sociologie. 1. Sociologický subjektivism. 2. Psychologickosociologický objektivism.“ Česká mysl 13(3): 289-305; 13(4): 393-405.

BLÁHA, Inocenc Arnošt. 1913. „Kritický realism v sociologii.“ Česká mysl 14(1): 52-58; 14(2): 172186.

BLÁHA, Inocenc Arnošt. 1926. „René Worms.“ Česká mysl 22(5): 303-305.

BLÁHA, Inocenc Arnošt. 1929. „Dnešní stav sociologie a její hlavní problémy.“ Česká mysl 25(5): 407-417.

BLÁHA, Inocenc Arnošt. 1936. „Social Psychology of the Intelligentsia.“ Social Science 11(3): 196-201.

BLÁHA, Inocenc Arnošt. 1937. „XIII. mezinárodní sociologický kongres v Paříži.“ Věstník Československé akademie zemédělské 13(8-9): 713-714.

BLÁHA, Inocenc Arnošt. 1968. Sociologie. Praha: Academia.

BLÁHA, Inocenc Arnošt. 1996-2004. „Rodinná kronika.“ Universitas, revue Masarykovy univerzity v Brně 29-37 (samostatně číslované př́lohy): 1-218.

BOURDIEU, Pierre. 2002. „Les conditions sociales de la circulation internationale des idées.“ Actes de la recherche en sciences sociales 5(145): 3-8.

BOURDIEU, Pierre. 2010. Pravidla uméní. Vznik a struktura literárního pole. Brno: Host.

CLARK, Terry Nichols. 1973. Prophets and Patrons: The French University and the Emergence of the Social Sciences. Cambridge, MA: Harvard University Press.

COLLINS, Randall. 1998. The Sociology of Philosophies: A Global Theory of Intellectual Change. Cambridge, MA: Belknap/Harvard University Press.

CUIN, Charles-Henry a François GRESLE. 2004. Dějiny sociologie. Praha: Sociologické nakladatelství.

ELLWOOD, Charles A. 1933. Methods in Sociology: A Critical Study. Durham: Duke University Press.

FLECK, Christian. 2015. Etablierung in der Fremde: Vertriebene Wissenschaftler in den USA nach 1933. Frankfurt/Main: Campus Verlag.

HEILBRON, Johan. 2015. French Sociology. Ithaca: Cornell University Press.

CHALUPNÝ, Emanuel. 1935. „Masarykova sociologická společnost. K desetiletí její činnosti.“ Sociologická revue 6(1-2): 79-89.

JANÁK, Dušan. 2006. „I. A. Bláha a počátky sociologie města u nás.“ Sociální studia/ Social Studies 3(2): 11-32. 
JANÁK, Dušan. 2014. „Obrdlík Antonín.“ Pp. 289-291 in Zdeněk R. NEŠPOR a kol. Slovník českých sociologů. Praha: Academia.

JANÁK, Dušan. 2018. Klasická sociologie ve středni Evropě: Mezi centrem a periferii. Praha: Sociologické nakladatelství.

KÄSLER, Dirk. 1991. Sociological Adventures: Earle Edward Eubank's Visits with European Sociologists. New Brunswick, NJ: Transaction Publishers.

MACHOTKA, Otakar. 1949. „Is Sociology a Natural Science?“ American Journal of Sociology 55(1): $10-17$.

MACHOTKOVÁ, Jarmila 2001. „Ze vzpomínek Jarmily Machotkové.“ Pp. 148-176 in Otakar MACHOTKA. Mezi domovem a exilem. Praha: MAROLI 2001.

MERTL, Jan. 1935. „Dnešní sociologie na XII. kongresu Mezinárodního sociologického ústavu.“ Sociální problémy 4(4): 245-261.

MOEBIUS, Stephan a Andrea PLODER (eds.). 2017. Handbuch Geschichte der deutschsprachigen Soziologie. Band 2: Forschungsdesign, Theorien und Methoden. Wiesbaden: Springer VS.

MUSIL, Jiří. 2012. „Chicagská škola a česká sociologie.“ Lidé města / Urban People 14(3): 395-419.

NEŠPOR, Zdeněk R. a kol. 2014. Dějiny české sociologie. Praha: Academia.

NEŠPOR, Zdeněk R. 2017. „,Opustíš-li mne, zahyneš...'Akademická dráha Otakara Machotky a dalších českých sociologů v emigraci po únoru 1948.“ Sociologický časopis / Czech Sociological Review 53(5): 737-764.

NEŠPOR, Zdeněk R. a Anna KOPECKÁ (eds.). 2011. Edice českých sociologických časopisů. [CD-ROM]. Praha: Sociologický ústav AV ČR.

NICHOLS, Lawrence T. 1996. „Sorokin and American Sociology: The Dynamics of a Moral Career in Science.“ Pp. 45-64 in Joseph B. FORD, Michel P. RICHARD a Palmer C. TALBUTT (eds.). Sorokin and Civilization: A Centennial Assessment. New Brunswick: Transaction Publishers.

OBRDLÍK, Antonín. 1934a. „O novou metodu v americké sociologii.“ Česká mysl 30(1): 31-35.

OBRDLÍK, Antonín. 1934b. „Gaston Richard. Přehled jeho myslitelské práce.“ Sociologická revue 5(4): 312-320.

OBRDLÍK, Antonín. 1935. „Democracy as a Sociological Problem.“ Social Science 10(3): 219-226.

OBRDLÍK, Antonín. 1936a. „Sociological Activities in Czechoslovakia.“ American Sociological Review 1(4): 653-656.

OBRDLÍK, Antonín. 1936b. „Social Attitudes of the Czechoslovakian Peasant Towards the Other Occupational Groups." Rural Sociology 1(3): 296-305.

OBRDLÍK, Antonín. 1937. Povolání a veřejné blaho: prestiž povoláni a veřejné blaho ve světle sociálních postoju․ Sociologická knihovna. Větší řada sv. V. Praha: Orbis.

OBRDLÍK, Antonín J. 1942. „,Gallows Humor“ - A Sociological Phenomenon.“ American Journal of Sociology 47(5): 709-716.

OBRDLÍK, Antonín. 1946. „Politická věda.“ Sociologická revue 12(5): 48-59.

OBRDLÍK, Antonín J. 1970. „Sociology in the Service of UN Experts.“ Sborník praci Filosofické fakulty brněnské univerzity G 14: 159-167.

OBRDLÍK, Antonín a Bruno ZWICKER. 1937. „Survey of Recent Sociological Production in Czechoslovakia.“ American Sociological Review 2(3): 424-427.

ROL, Cécile. 2011. „Guillaume-Léonce Duprat (1872-1956), l'Institut International de Sociologie et l'Allemagne dans l'entre-deux-guerres.“ Lendemains - Etudes comparées sur la France 36(141): 18-42.

SCHRECKER, Cherry (ed.). 2010. Transatlantic Voyages and Sociology: The Migration and Development of Ideas. Aldershot, UK: Ashgate.

SOROKIN, Pitirim A. 1938. „Posudek Prof. P. A. Sorokina o knize Dr. Ant. Obrdlíka: Povolání a veřejné blaho." Sociologická revue 9(1-2): 227-228. 
TURNER, Stephen P. 2010. „Ellwood's Europe.“Pp. 163-176 in Cherry SCHRECKER (ed.). Transatlantic Voyages and Sociology: The Migration and Development of Ideas. Aldershot: Ashgate.

TURNER, Stephen P. a Jonathan H. TURNER. 1990. The Impossible Science: An Institutional Analysis. Newbury Park: Sage.

ULLRICH, Zdeněk. 1932. „Dr. Ant. Uhlíř: ,Sociologická idea (sociální věda)‘. Praha 1932, nákladem O. Janáčka, str. 257.“ Sociálni problémy 2(2): 149-164.

ULLRICH, Zdeněk. 1938-1939. „XIII. Mezinárodní sociologický kongres.“ Sociální problémy 6(1-2): 83-88.

WIRTH, Louis. 1933. „Studující sociologie a volba povolání.“ Sociologická revue 4(2-3): 266-268.

\section{Autor}

Marek Skovajsa vyučuje na katedře sociologie Filozofické fakulty Univerzity Karlovy a na Fakultě humanitních studií Univerzity Karlovy. Zabývá se sociologickou teorií, dějinami sociologie a sociologií kultury.

Kontakt: marek.skovajsa@ff.cuni.cz,marek.skovajsa@fhs.cuni.cz 